\title{
Studies of phenotypic and genotypic variation in sixteen cucumber genotypes
}

Chikezie O. Ene ${ }^{1 *}$, Peter E. Ogbonna ${ }^{1}$, Christian U. Agbo ${ }^{1}$, and Uche P. Chukwudi ${ }^{1}$

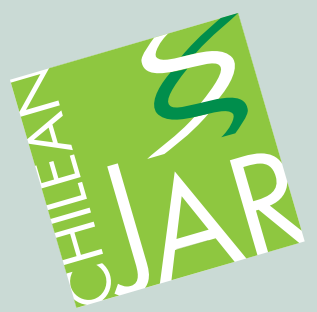

\section{ABSTRACT}

Genetic variability in a crop population is important for successful plant breeding. Sixteen cucumber (Cucumis sativus L.) genotypes were evaluated in the early and late planting seasons to estimate the magnitude of their genetic variability and heritability. Genotypes were also classified into groups based on the performance and determination of the highest discriminating trait that accounted for greater variability using cluster analysis and principal component analysis (PCA), respectively. The measured agronomic traits were vine length, number of branches, number of leaves, and leaf area $8 \mathrm{wk}$ after planting, days to flower initiation, days to $50 \%$ flowering, number of staminate flowers per plant, number of pistillate flowers per plant, fruit length, fruit girth, fruit weight per plant, number of fruits per plant, mean fruit weight, and total fruit yield ha-1. A high coefficient of variation was recorded for most traits in both seasons and high variability was found among genotypes. High broad-sense heritability was associated with all the traits in both seasons, except for mean fruit weight in the early planting season and fruit girth, mean fruit weight, and total fruit yield in late planting season. Cluster analysis and its comparison of means showed that 'Beit Alpha', 'Ashely', 'Straight 8', and 'Sumter' from cluster F in the early planting season and 'Beit Alpha' and 'Ashely' from cluster $\mathrm{E}$ in the late planting season expressed the best agronomic traits and yield potentials. Hence, selection for any trait would favor genotypes in these clusters. Principal component analysis involved vine length as the most discriminating trait that accounted for greater variability in cucumber in both the early and late planting seasons, and it should be considered in cucumber improvement programs.

Key words: Cucumis sativus, genetic advance, heritability, principal component.

${ }^{1}$ University of Nigeria, Nsukka, Department of Crop Science, Enugu State, Nigeria. "Corresponding author (enechike17@gmail.com).

Received: 1 December 2015.

Accepted: 15 April 2016.

doi:10.4067/S0718-58392016000300007

\section{INTRODUCTION}

Cucumber (Cucumis sativus L.) belongs to the Cucurbitaceae family. It has been cultivated for at least 3000 years (Ullah et al., 2012). It is believed to have originated in India, southern Asia (Papadopoulos, 1994; Haifa Chemicals, 2012). It is an important fruit with great nutritional, medicinal, and economic potential. The use of local unimproved stocks for production has resulted in very low cucumber yields in Nigeria (Eneobong, 2001). Cucumber growing time is shorter from planting to harvest than most crops (Wehner and Guner, 2004). This probably contributes to making it the second most cultivated vegetable crop, after tomatoes, in Western Europe and the fourth after tomatoes, brassicas, and onions in Asia and worldwide (Wehner, 2007). In tropical Africa, its place has not been ranked perhaps because of low yield and insufficient use of the product (Eifediyi and Remison, 2009).

With recent campaigns about fruit and vegetable consumption to promote good health and longevity, it is expected that the consumption of vegetables, such as cucumber, can increase in Nigeria (Eneobong, 2001; Afangideh and Uyoh, 2007), and this increase must be equaled by increased cucumber production.

Genetic variability in crop breeding lines is important for successful plant breeding. Determining variability in yield and yield components of different cucumber genotypes will enable a breeder to know to what extent the environment affects yield (Ahmed and Khaliq, 2007; Ullah et al., 2012). Direct selection only for higher yield could be misleading because many factors interact to determine crop yield (Gatti et al., 2005). Separate yield components are less influenced by the environment than yield itself; hence, selection for such yield components can be useful to acquire genotypes with better yield abilities (Gatti et al., 2005). Heritability provides evidence for genetic control for the expression of a given trait and phenotypic reliability to predict its breeding value (Ullah et al., 2012). It also estimates genetic advance that a breeder can expect from selection and which breeding method to adopt (Ullah et al., 2012).

The success of any breeding program greatly depends on the genetic diversity available in the population (Afangideh et al., 2005; Subramanian and Subbaraman, 2010). Hierarchical cluster analysis highlights the nature of relationships between some samples described by some type of descriptor. It classifies the genotypes into different groups based on Euclidian distance and chooses parental lines that could yield superior hybrids (Subramanian and Subbaraman, 2010). Principal component analysis (PCA) usually suggests the traits that contribute a lot, a little, or not at all to the 
variation among treatments. Principal component analysis shows which trait explains greater variability and is the most discriminating among treatments.

Therefore, the present study was carried out to estimate genetic variability and heritability, and evaluate cucumber genotypes using cluster analysis and PCA as tools.

\section{MATERIALS AND METHODS}

The experiment was carried out in the Department of Crop Science Experimental farm, Faculty of Agriculture, University of Nigeria, Nsukka. Nsukka (6 $51^{\prime}$ E, $7^{\circ} 29^{\prime}$ N; $475 \mathrm{~m}$ a.s.1.), is characterized by lowland humid conditions with bimodal annual rainfall distribution that ranges from 1155 to $1955 \mathrm{~mm}$, mean annual temperature of 29 to $31{ }^{\circ} \mathrm{C}$, and relative humidity that ranges from $69 \%$ to $79 \%$ (Uguru et al., 2011). Sixteen cucumber genotypes obtained from the National Agricultural Extension, Research and Liaison Services (NAERLS), Ahmadu Bello University, Samaru Zaria, were used for the trial. They included 'Beit Alpha', 'Delilha', 'Zeina', 'Palmetto', 'Straight 8', 'Table green 72', 'Poinsett', 'Centriolo', 'Regal', 'Sumter', 'Ashely', 'Royal F1', 'Market more 76', 'W12757', 'Calypso', and 'Marketer' (Table 1). They were evaluated in the 2014 early (May to July) and late (September to November) planting seasons in a randomized complete block design (RCBD) with three replicates. Recorded monthly rainfall distribution, relative humidity, and temperature during this period are displayed in Table 2. The field was prepared and divided into three blocks. Poultry droppings, at the rate of $10 \mathrm{t} \mathrm{ha}^{-1}$, were worked into the soil in each block. Each block measured $3 \times 40 \mathrm{~m}$ with 16 plots each of which measured $3 \times 2 \mathrm{~m}$ and contained one of the 16 genotypes. Seeds were planted with $0.5 \mathrm{~m}$ intra- and $0.5 \mathrm{~m}$ inter-row spacing, which was expected to produce a plant population of 40000 stands ha $^{-1}$. Two seeds were sown at the 3-4 $\mathrm{cm}$ depth and were thinned to one seedling $3 \mathrm{wk}$ after emergence (WAE). In each case NPK 20:10:10 fertilizer was applied at 2 and 5 wk after

Table 1. Origin and source of cucumber collection for the trial carried out in Nsukka, Nigeria.

\begin{tabular}{rllc}
\hline S/N & Accessions & \multicolumn{1}{c}{ Origin } & Remark \\
\hline 1 & Zeina & NIHORT & Indigenous \\
2 & Delilha & NIHORT & Indigenous \\
3 & Beit Alpha & NIHORT & Indigenous \\
4 & Calypso & Cucumber Breeding Station, NCSU, USA & Exotic \\
5 & Regal & Cucumber Breeding Station, NCSU, USA & Exotic \\
6 & Royal F1 & Cucumber Breeding Station, NCSU, USA & Exotic \\
7 & Centriolo & Cucumber Breeding Station, NCSU, USA & Exotic \\
8 & Ashely & Cucumber Breeding Station, NCSU, USA & Exotic \\
9 & Straight 8 & Cucumber Breeding Station, NCSU, USA & Exotic \\
10 & Sumter & Cucumber Breeding Station, NCSU, USA & Exotic \\
11 & W12757 & Cucumber Breeding Station, NCSU, USA & Exotic \\
12 & Tablegreen 72 & Cucumber Breeding Station, NCSU, USA & Exotic \\
13 & Marketmore 76 Cucumber Breeding Station, NCSU, USA & Exotic \\
14 & Poinsett & Cucumber Breeding Station, NCSU, USA & Exotic \\
15 & Marketer & Cucumber Breeding Station, NCSU, USA & Exotic \\
16 & Palmetto & Cucumber Breeding Station, NCSU, USA & Exotic \\
\hline
\end{tabular}

NIHORT: Nigerian Horticultural Research Center Ibadan, Nigeria. NCSU, USA: North Carolina State University, United States of America.
Table 2. Mean monthly rainfall, temperature, and relative humidity during the 2014 early and late planting seasons.

\begin{tabular}{|c|c|c|c|c|c|}
\hline \multirow[b]{2}{*}{ Month } & \multirow[b]{2}{*}{ Rainfall } & \multicolumn{2}{|c|}{ Temperature } & \multicolumn{2}{|c|}{ Relative humidity } \\
\hline & & Min & $\operatorname{Max}$ & $10: 00 \mathrm{~h}$ & $16: 00 \mathrm{~h}$ \\
\hline & $\mathrm{mm}$ & \multicolumn{2}{|c|}{$-{ }^{\circ} \mathrm{C}$} & \multicolumn{2}{|c|}{$\%$} \\
\hline April & 105.16 & 22.30 & 31.30 & 69.93 & 70.53 \\
\hline May & 241.14 & 21.06 & 28.29 & 72.26 & 72.26 \\
\hline June & 271.79 & 20.87 & 29.13 & 72.00 & 72.00 \\
\hline July & 195.81 & 20.9 & 27.74 & 72.19 & 72.19 \\
\hline August & 92.36 & 20.71 & 27.29 & 73.00 & 73.00 \\
\hline September & 401.99 & 20.33 & 27.90 & 73.00 & 73.00 \\
\hline October & 211.08 & 20.84 & 28.90 & 73.00 & 72.77 \\
\hline November & 77.22 & 21.00 & 30.07 & 73.80 & 71.97 \\
\hline December & 4.83 & 19.03 & 30.65 & 70.58 & 70.06 \\
\hline
\end{tabular}

Source: Meteorological Station, Department of Crop Science, University of Nigeria, Nsukka.

seedling emergence at the rate of $300 \mathrm{~kg} \mathrm{ha}^{-1}$ after manual weeding. Insecticide (cypermethrin $110 \%$ EC sprayed at $125 \mathrm{~mL}$ in $15 \mathrm{~L}$ water; Cyper Force, Quick Company, Kolkata, West Bengal, India) and fungicide (maneb, mancozeb, and zoxamide at $75 \mathrm{~mL}$ in $15 \mathrm{~L}$ water; Gavel, Gowan Company, Yuma, Arizona, USA) were applied twice ( 2 and 4 WAE) to curtail insect attack and disease incidence in young plants. Growth traits were measured 8 wk after planting. These traits included vine length, number of branches, number of leaves, and leaf area. The recorded reproductive traits included days to flower initiation, days to $50 \%$ flowering, number of staminate flowers per plant, and number of pistillate flowers per plant. Yield traits measured immediately after harvest were fruit length, fruit girth, fruit weight per plant, number of fruits per plant, mean fruit weight, and total fruit yield per hectare.

\section{Statistical analysis}

Collected data were subjected to ANOVA for RCBD using GenStat Release 10.3 Discovery Edition (PC/Windows; VSN International, Hemel Hempstead, Hertfordshire, UK). Means were used to calculate genetic parameters such as genotypic coefficient of variation (GCV), phenotypic coefficient of variation (PCV), environmental coefficient of variation $(\mathrm{ECV})$, genotypic variance, phenotypic variance, environmental variances, coefficient of variation (CV), and genetic advance to show variability among genotypes. Principal component and hierarchical cluster analyses were also carried out with GenStat Release 10.3 Discovery Edition to show the highest discriminating trait and level of relationship, respectively, among the cucumber genotypes. The phenotypic variation for each trait was separated into genetic and non-genetic factors and estimated according to Burton (1952) and Sharma (1988):

$$
\sigma_{e}^{2}=M S_{e} ; \sigma_{g}^{2}=\left(M S_{g}-M S_{e}\right) / r ; \sigma_{p}^{2}=\sigma_{g}^{2}+\sigma_{e}^{2}
$$

where $\sigma_{p}^{2}, \sigma_{g}^{2}$, and $\sigma_{e}^{2}$ are phenotypic variance, genotypic variance, and environmental variance, respectively, and $M S_{g}$, $M S_{e}$, and $r$ are the mean squares of genotypes, mean squares of error, and number of blocks, respectively.

$$
\% C V=\frac{\sqrt{M S_{g}}}{\bar{X}} \times 100
$$




$$
\begin{gathered}
P C V=\frac{\sqrt{\sigma_{p}^{2}}}{\bar{X}} \times 100 \\
G C V=\frac{\sqrt{\sigma_{g}^{2}}}{\bar{X}} \times 100 \\
E C V=\frac{\sqrt{\sigma_{e}^{2}}}{\bar{X}} \times 100
\end{gathered}
$$

where $\bar{X}$ is the grand mean for each measured trait. Broadsense heritability $\left(h_{b s}^{2}\right)$ is expressed as the percentage of the ratio between the genotypic variance $\left(\sigma_{g}^{2}\right)$ and phenotypic variance $\left(\sigma_{p}^{2}\right)$ that was estimated according to Burton (1952). Genetic advance ( $G A)$ was estimated by the methods described by Fehr (1987) as $G A=K\left(S_{p}\right) h^{2}$ ss where $K$ is a constant (2.06) at 5\% selection pressure, $S_{p}$ is the phenotypic standard deviation $\left(\sqrt{\sigma_{p}^{2}}\right)$ and $h^{2}$ ss is the heritability ratio. GA was also calculated as percentage of the mean.

\section{RESULTS AND DISCUSSION}

\section{Genetic variability}

Genetic variability in breeding materials is essential for a successful plant breeding program. Understanding the magnitude of variability in crop species is pivotal since it provides the foundation for selection. The mean squares and genetic parameters of 16 genotypes of cucumber planted in the early and late rainy seasons of 2014 are displayed in Table 3. The ANOVA showed a highly significant $(\mathrm{p}<$ 0.01 ) variation for all the studied traits in the genotypes in the early rainy season experiment, except for mean fruit weight that was marginally significant $(\mathrm{p}<0.05)$. A similar result was obtained in the late rainy season planting. The significant differences observed among the genotypes for all the traits in both the early and late rainy season plantings

\begin{tabular}{|c|c|c|c|c|c|c|c|c|c|c|c|}
\hline Traits & Mean & $\sigma_{\mathrm{p}}^{2}$ & $\sigma_{\mathrm{g}}^{2}$ & $\sigma_{\mathrm{e}}^{2}$ & PCV & GCV & ECV & $\% \mathrm{CV}$ & $\mathrm{H}^{2}{ }_{\mathrm{bs}}(\%)$ & GA & $\mathrm{MSg}$ \\
\hline \multicolumn{12}{|c|}{ Early planting season } \\
\hline VL8WAP & 143.67 & 12662.65 & 12650.85 & 11.80 & 78.32 & 78.29 & 2.39 & 135.62 & 99.91 & 231.60 & $37964.34 * *$ \\
\hline LA8WAP & 89.66 & 3324.69 & 3294.21 & 30.48 & 64.31 & 64.01 & 6.16 & 111.05 & 99.08 & 117.69 & $9913.10 * *$ \\
\hline NoB8WAP & 2.16 & 3.75 & 3.23 & 0.52 & 89.65 & 83.20 & 33.38 & 147.90 & 86.13 & 3.44 & $10.21 * *$ \\
\hline NoL8WAP & 24.81 & 171.57 & 168.53 & 3.04 & 52.80 & 52.33 & 7.03 & 90.90 & 98.23 & 26.51 & $598.62 * *$ \\
\hline DMFI & 28.52 & 25.79 & 24.89 & 0.90 & 17.81 & 17.49 & 3.33 & 30.48 & 96.51 & 10.10 & $75.55 * *$ \\
\hline DFFI & 38.33 & 27.79 & 26.06 & 1.73 & 13.75 & 13.32 & 3.43 & 23.32 & 93.77 & 10.18 & $79.91 * *$ \\
\hline $\mathrm{D} 50 \% \mathrm{MF}$ & 36.96 & 27.38 & 26.28 & 1.10 & 14.16 & 13.87 & 2.84 & 24.19 & 95.98 & 10.35 & $79.95 * *$ \\
\hline D50\%FF & 46.75 & 30.14 & 29.12 & 1.02 & 11.74 & 11.54 & 2.16 & 20.11 & 96.62 & 10.93 & $88.38 * *$ \\
\hline NoPFPP & 3.56 & 3.07 & 2.91 & 0.16 & 49.22 & 47.92 & 11.24 & 83.77 & 94.79 & 3.42 & $8.89 * *$ \\
\hline NoSFPP & 12.50 & 20.12 & 19.55 & 0.57 & 35.88 & 35.37 & 6.04 & 61.56 & 97.17 & 8.98 & $59.22 * *$ \\
\hline $\mathrm{FG}$ & 15.03 & 15.13 & 14.59 & 0.54 & 25.88 & 25.41 & 4.89 & 44.28 & 96.43 & 7.73 & $44.30 * *$ \\
\hline FL & 15.58 & 20.35 & 19.70 & 0.65 & 28.95 & 28.49 & 5.17 & 49.62 & 96.81 & 9.00 & $59.76 * *$ \\
\hline FWPP & 0.96 & 0.42 & 0.40 & 0.02 & 67.51 & 65.88 & 14.73 & 114.88 & 95.24 & 1.27 & $1.22 * *$ \\
\hline AFW & 0.18 & 0.01 & 0.00 & 0.01 & 63.34 & 30.43 & 55.56 & 69.64 & 23.08 & 0.05 & $0.02 *$ \\
\hline NoFPP & 6.40 & 16.16 & 15.82 & 0.34 & 62.81 & 62.15 & 9.11 & 108.04 & 97.90 & 8.11 & $47.81 * *$ \\
\hline TFY ha-1 & 9.69 & 2.25 & 2.13 & 0.12 & 59.76 & 58.15 & 13.80 & 101.57 & 94.67 & 2.93 & $6.50 * *$ \\
\hline \multicolumn{12}{|c|}{ Late planting season } \\
\hline VL8WAP & 126.44 & 11280.63 & 10821.93 & 458.70 & 84.00 & 82.27 & 16.94 & 143.51 & 95.93 & 209.89 & $32924.50 * *$ \\
\hline LA8WAP & 77.02 & 3353.00 & 2305.00 & 1048.00 & 75.18 & 62.33 & 42.03 & 115.87 & 68.74 & 82.00 & $7964.00 * *$ \\
\hline NoB8WAP & 2.08 & 3.53 & 2.83 & 0.70 & 90.33 & 80.92 & 40.12 & 145.79 & 80.25 & 3.11 & $9.20 * *$ \\
\hline NoL8WAP & 21.85 & 177.35 & 166.91 & 10.44 & 60.95 & 59.13 & 14.79 & 103.47 & 94.11 & 25.82 & $511.16 * *$ \\
\hline DMFI & 30.50 & 27.40 & 26.54 & 0.86 & 17.16 & 16.89 & 3.04 & 29.41 & 96.86 & 10.44 & $80.49 * *$ \\
\hline DFFI & 40.46 & 29.75 & 28.19 & 1.56 & 13.48 & 13.12 & 3.09 & 22.94 & 94.76 & 10.65 & $86.13 * *$ \\
\hline D50\%MF & 39.10 & 29.93 & 28.63 & 1.30 & 14.00 & 13.68 & 2.92 & 23.88 & 95.66 & 10.78 & $87.19 * *$ \\
\hline D50\%FF & 48.56 & 28.89 & 24.70 & 4.19 & 11.07 & 10.23 & 4.22 & 18.22 & 85.50 & 9.47 & $78.30 * *$ \\
\hline NoPFPP & 1.89 & 1.95 & 1.14 & 0.81 & 73.92 & 56.57 & 47.59 & 108.94 & 58.56 & 1.69 & $4.24 * *$ \\
\hline NoSFPP & 9.32 & 19.20 & 12.15 & 7.05 & 47.01 & 37.40 & 28.49 & 70.76 & 63.28 & 5.71 & $43.49 * *$ \\
\hline $\mathrm{FG}$ & 13.91 & 13.36 & 6.56 & 6.80 & 26.28 & 18.41 & 18.75 & 37.01 & 49.10 & 3.70 & $26.50 * *$ \\
\hline FL & 14.34 & 17.84 & 9.02 & 8.82 & 29.45 & 20.94 & 20.71 & 41.78 & 50.56 & 4.40 & $35.89 * *$ \\
\hline FWPP & 0.77 & 0.51 & 0.32 & 0.19 & 92.75 & 73.47 & 56.37 & 139.22 & 62.75 & 0.92 & $1.15 * *$ \\
\hline AFW & 0.12 & 0.00 & 0.00 & 0.00 & 47.14 & 32.27 & 34.36 & 66.45 & 46.88 & 0.06 & $0.01 *$ \\
\hline NoFPP & 5.51 & 8.31 & 6.36 & 1.96 & 52.33 & 45.76 & 25.38 & 83.22 & 76.47 & 4.54 & $21.03 * *$ \\
\hline TFY ha-1 & 4.93 & 2.32 & 1.11 & 1.21 & 75.44 & 52.20 & 54.46 & 105.55 & 47.89 & 1.50 & $4.55 * *$ \\
\hline
\end{tabular}

Table 3. Mean square and genetic parameters for some quantitative traits in 16 cucumber genotypes in 2014 early and late planting seasons.

VL8WAP: vine length $8 \mathrm{wk}$ after planting $(\mathrm{cm})$; LA8WAP: leaf area $8 \mathrm{wk}$ after planting $\left(\mathrm{cm}^{2}\right)$; NoB8WAP: number of branches 8 wk after planting; NoL8WAP: number of leaves $8 \mathrm{wk}$ after planting; DMFI: days to male flower initiation; DFFI: days to female flower initiation; D50\%MF: days to 50\% male flowering; D50\%FF: days to 50\% female flowering; NoPFPP: number of pistillate flowers per plant; NoSFPP: number of staminate flowers per plant; FG: fruit girth (cm); FL: fruit length $(\mathrm{cm})$; FWPP: fruit weight per plant $(\mathrm{kg})$; AFW: mean fruit weight $(\mathrm{kg})$; NoFPP: number of fruit per plant; TFY ha ${ }^{-1}$ : total fruit yield per hectare $\left(\mathrm{t} \mathrm{ha}^{-1}\right) ; \sigma_{\mathrm{P}}^{2}$ phenotypic variance; $\sigma_{\mathrm{g}}^{2}$ genotypic variance; $\sigma_{\mathrm{e}}^{2}$ environmental variance; GCV: genotypic environmental coefficient of variation; PCV: phenotypic environmental coefficient of variation; ECV: environmental coefficient of variation; \%CV: percentage coefficient of variation; $\mathrm{GA}$ : genetic advance; $\mathrm{H}^{2}$;s: broad-sense heritability; MSg: mean square of genotypes. Significance codes according to ANOVA F-test (P value): $* * * 0.001$ (very highly significant); $* * 0.01$ (highly significant); *0.05 (significant); and ns (nonsignificant) $(\mathrm{P}>0.05)$. 
suggest the existence of inherent genetic variability among the genotypes. Afangideh and Uyoh (2007) reported the existence of genetic variation among cucumber genotypes. The same was reported for other crops from the same family such as egusi-melon (Colocynthis citrullus [L.] Kuntze) genotypes regarding the number of branches per plant, vine length per plant, number of pods per plant, and seed yield per plant (Kehinde, 2008; Olaniyi et al., 2011), and pumpkin (Cucurbita pepo L.) (Aruah et al., 2012). Genetic variation in any given crop population is essential to successfully select and manage yield improvement programs (Idahosa et al., 2010; Ndukauba et al., 2015). The coefficient of variation $(\% \mathrm{CV})$ compares the relative amount of variability between crop plant traits (Sharma, 1988). In the early rainy season experiment, the highest coefficient of variation was obtained by the number of branches followed by vine length and fruit weight per plant. The results for the late plantings followed a similar trend. The highest coefficient of variation was recorded for the number of branches followed by vine length and fruit weight per plant (Table 3 ). These results imply that the number of branches, vine length, and fruit weight per plant, in that order, had higher amounts of exploitable genetic variability among the studied cucumber attributes. It also means that there is greater potential for favorable advance in selecting these attributes compared to others (Eid, 2009; Ndukauba et al., 2015). Conversely, the lowest $\% \mathrm{CV}$ was recorded for days to $50 \%$ female flowering in both the early and late plantings, respectively: this shows low exploitable genetic variability and, as a result, has less potential for favorable advance in selecting when compared to other traits.

The phenotypic variance of the traits under study was divided into heritable (genotypic variance) and non-heritable (environmental variance) components in both planting seasons (Table 3). The magnitude of genotypic variances was higher than their corresponding environmental variances for all the traits, except for mean fruit weight that was very negligible. This indicates that the genotypic component of variation was the major contributor to total variation in the studied traits. The highest phenotypic coefficient of variation (PCV) was obtained for the number of branches followed by vine length, fruit weight per plant, and leaf area while the least PCV was recorded for days to $50 \%$ female flowering in the early planting season. For the late planting season, the highest PCV was recorded in fruit weight per plant followed by number of branches, vine length, and total fruit yield ha-1 while days to $50 \%$ female flowering had the lowest PCV. High PCV indicates the existence of a greater scope of selection for the trait being considered, which depends on the amount of variability present (Khan et al., 2009). Thus, a greater potential is expected in selecting for the number of branches, vine length, fruit weight per plant, leaf area, and total fruit yield ha-1 among the studied cucumber genotypes. On the other hand, there is a narrow scope of selection for days to $50 \%$ female flowering because of low variability. The genotypic coefficient of variation (GCV) provides a measure of genetic variability that exists in different quantitative traits. The highest GCV was obtained for the number of branches followed by vine length, fruit weight per plant, and leaf area; the lowest GCV was recorded for days to $50 \%$ female flowering in the early planting season. The highest GCV for the late planting season was recorded in vine length followed by number of branches, fruit weight per plant; and leaf area; the lowest GCV was recorded for days to $50 \%$ female flowering. High GCV indicates the presence of exploitable genetic variability for the traits, which can facilitate selection (Yadav et al., 2009). The environmental coefficient of variation (ECV) ranged from $2.16 \%$, obtained for days to $50 \%$ female flowering, to $55.56 \%$ recorded for mean fruit weight in the early planting season. For the late planting season, ECV ranged from $2.92 \%$, for days to $50 \%$ male flowering, to $56.37 \%$ in fruit weight per plant. Although estimates for PCV were higher than those for GCV, they were close, implying that genotype contributed more than environment in the expression of these characters and selection based on phenotypic values is therefore feasible. Similar observations were also reported by Afangideh and Uyoh (2007) in cucumber for days to flower initiation and observed by Rakhi and Rajamony (2005) for most traits of culinary melon. In comparison, a greater difference between PCV and GCV estimates for mean fruit weight and number of branches indicates a greater degree of environmental control for these traits. Polygenic variation can be phenotypic, genotypic, or environmental and the relative values of these three coefficients for a trait will provide information about the magnitude of variability (Nausherwan et al., 2008; Ndukauba et al., 2015).

\section{Heritability estimates}

Heritability estimates give an insight into the extent of genetic control to express a particular trait and phenotypic reliability in predicting its breeding value (Ndukauba et al., 2015). High heritability indicates less environmental influence in the observed variation (Eid, 2009). Broad-sense heritability $\left(\mathrm{h}^{2} \mathrm{bs}\right)$ only indicates whether or not there is sufficient genetic variation in a population, which implies whether or not a population will respond to selection pressure (Gatti et al., 2005; Milatovic et al., 2010; Ullah et al., 2012). High $\mathrm{h}^{2}$ bs was recorded in all the traits, except for mean fruit weight in the early planting season. A similar result was recorded for the late planting season, except for mean fruit weight and total fruit yield ha- ${ }^{-1}$ that had relatively low $\mathrm{h}^{2}$ bs (Table 3 ). These results indicate that there is considerable genetic variation present in these traits to warrant selection for better accessions. These traits can therefore be given special attention for selections aimed at cucumber improvement. To access a more effective trait selection, heritability accompanied by genetic advance is more useful than heritability alone (Ullah et al., 2012). In the present study, although high $\mathrm{h}^{2}$ bs estimates were recorded for most of the traits in both the early and late planting seasons, they were associated with low genetic advance (GA; Table 3 ). The high heritability observed might be due to the favorable influence of the environment rather than the genotype, and simple 
selection will therefore not be worthwhile. However, these traits could be improved by developing hybrid varieties or isolating transgressive segregants in heterosis. High heritability and high GA for a given trait indicates that it is governed by additive gene action and therefore provides the most effective condition for selection (Tazeen et al., 2009; Ndukauba et al., 2015). The highest GA for vine length and leaf area in both the early and late planting seasons suggest that the variation in these traits was mainly genetic with less environmental influence coupled with the prevalence of additive gene action in their inheritance (Tazeen et al., 2009).

\section{Cluster analysis}

Genotype cluster mean values are shown in Table 4. Comparing cluster means with studied traits revealed considerable variation among different groups in both planting seasons. According to the dendrogram for the early planting season, 16 genotypes were classified into

Table 4. Cluster mean for some agronomic traits used in the classification of cucumber genotypes in 2014 early and late planting seasons.

\begin{tabular}{|c|c|c|c|c|c|c|}
\hline Traits & $\begin{array}{c}\text { Cluster } \\
\text { A } \\
\text { mean }\end{array}$ & $\begin{array}{c}\text { Cluster } \\
\text { B } \\
\text { mean }\end{array}$ & $\begin{array}{c}\text { Cluster } \\
\text { C } \\
\text { mean }\end{array}$ & $\begin{array}{c}\text { Cluster } \\
\text { D } \\
\text { mean }\end{array}$ & $\begin{array}{c}\text { Cluster } \\
\text { E } \\
\text { mean }\end{array}$ & $\begin{array}{c}\text { Cluster } \\
\text { F } \\
\text { mean }\end{array}$ \\
\hline \multicolumn{7}{|c|}{ Early Planting Season } \\
\hline VL8WAP & 54.307 & 44.240 & 241.270 & 19.145 & 194.860 & 284.750 \\
\hline NoB8WAP & 0.777 & 0.787 & 2.780 & 0.000 & 3.383 & 4.250 \\
\hline NoL8WAP & 15.973 & 12.743 & 37.550 & 9.400 & 34.330 & 37.875 \\
\hline LA8WAP & 58.617 & 32.833 & 92.810 & 28.170 & 142.033 & 146.238 \\
\hline DMFI & 27.110 & 33.443 & 33.670 & 35.835 & 25.000 & 23.585 \\
\hline D50\%MF & 35.223 & 42.667 & 42.000 & 44.000 & 33.223 & 32.000 \\
\hline DFFI & 37.333 & 43.333 & 43.330 & 45.670 & 34.777 & 33.085 \\
\hline $\mathrm{D} 50 \% \mathrm{FF}$ & 45.443 & 51.223 & 52.000 & 54.000 & 42.223 & 42.833 \\
\hline NoSFPP & 8.620 & 8.947 & 9.380 & 9.095 & 16.027 & 17.900 \\
\hline NoPFPP & 2.197 & 2.170 & 2.510 & 2.105 & 4.607 & 5.820 \\
\hline NoFPP & 3.550 & 2.980 & 2.950 & 2.640 & 9.547 & 11.500 \\
\hline FL & 13.590 & 10.697 & 17.180 & 10.505 & 17.587 & 21.363 \\
\hline FG & 14.013 & 10.553 & 16.800 & 10.285 & 16.587 & 19.903 \\
\hline AFW & 0.227 & 0.177 & 0.320 & 0.155 & 0.107 & 0.168 \\
\hline TFY ha-1 & 6.501 & 4.045 & 9.602 & 1.951 & 9.652 & 19.182 \\
\hline FWPP & 0.650 & 0.490 & 0.960 & 0.195 & 0.957 & 1.918 \\
\hline \multicolumn{7}{|c|}{ Late Planting Season } \\
\hline VL8WAP & 35.578 & 27.710 & 223.600 & 213.750 & 238.750 & \\
\hline NoB8WAP & 0.583 & 0.590 & 2.780 & 3.548 & 4.010 & \\
\hline NoL8WAP & 11.743 & 8.680 & 35.960 & 31.512 & 37.160 & \\
\hline LA8WAP & 40.350 & 25.398 & 68.520 & 118.578 & 154.000 & \\
\hline DMFI & 30.000 & 37.500 & 36.000 & 26.668 & 24.330 & \\
\hline D50\%MF & 38.418 & 46.583 & 44.330 & 35.066 & 33.000 & \\
\hline DFFI & 40.335 & 47.585 & 45.670 & 36.666 & 33.330 & \\
\hline $\mathrm{D} 50 \% \mathrm{FF}$ & 48.250 & 55.335 & 53.000 & 45.398 & 41.335 & \\
\hline NoSFPP & 6.480 & 5.723 & 8.550 & 12.146 & 15.495 & \\
\hline NoPFPP & 0.975 & 0.795 & 1.750 & 2.740 & 3.860 & \\
\hline NoFPP & 3.630 & 2.698 & 5.710 & 7.844 & 8.985 & \\
\hline FL & 12.958 & 10.345 & 13.220 & 16.660 & 19.890 & \\
\hline $\mathrm{FG}$ & 13.010 & 10.218 & 13.030 & 15.884 & 18.610 & \\
\hline AFW & 0.083 & 0.078 & 0.110 & 0.146 & 0.195 & \\
\hline TFY ha-1 & 3.082 & 2.035 & 6.503 & 12.147 & 17.853 & \\
\hline FWPP & 0.308 & 0.203 & 0.650 & 1.214 & 1.785 & \\
\hline
\end{tabular}

VL8WAP: vine length $8 \mathrm{wk}$ after planting $(\mathrm{cm})$; LA8WAP: leaf area $8 \mathrm{wk}$ after planting $\left(\mathrm{cm}^{2}\right)$; NoB8WAP: number of branches 8 wk after planting; NoL8WAP: number of leaves 8 wk after planting; DMFI: days to male flower initiation; DFFI: days to female flower initiation; D50\%MF: days to $50 \%$ male flowering; D50\%FF: days to $50 \%$ female flowering; NoPFPP: number of pistillate flowers per plant; NoSFPP: number of staminate flowers per plant; FG: fruit girth $(\mathrm{cm})$; FL: fruit length $(\mathrm{cm})$; FWPP: fruit weight per plant (kg); AFW: mean fruit weight $(\mathrm{kg})$; NoFPP: number of fruit per plant; TFY ha-1: total fruit yield per hectare $\left(\mathrm{t} \mathrm{ha}^{-1}\right)$. five clusters and a lone genotype (outlier) at $90 \%$ on the similarity axis based on PCA (Figure 1). Cluster A consisted of 'Zeina', 'Palmetto', and 'Marketer' while cluster B consisted of 'W12757', 'Calypso', and 'Delilha'. Cluster C only included 'Poinsett' while cluster D consisted of 'Royal $\mathrm{F}_{1}$ ' and 'Marketmore 76'. 'Poinsett' performed better than clusters A, B, and D in all the studied traits among the genotypes, except for the number of fruits per plant (Table 4). Clusters A, B, and D recorded lower phenotypic values in most of the studied traits when compared to clusters C, E, and F. Cluster E consisted of 'Centriolo', 'TableGreen 72', and 'Regal'. They exhibited moderate to high performance in all the studied traits, except for mean fruit weight. Cluster F consisted of 'Beit Alpha', 'Ashely', 'Straight 8', and 'Sumter', which exhibited the highest and best mean performance in all the traits, except for mean fruit weight when compared to the other clusters. However, cluster F had the lowest value for days to both male and female flower

Figure 1. Dendrogram showing the classification of cucumber genotypes in 2014 early and late season planting seasons.
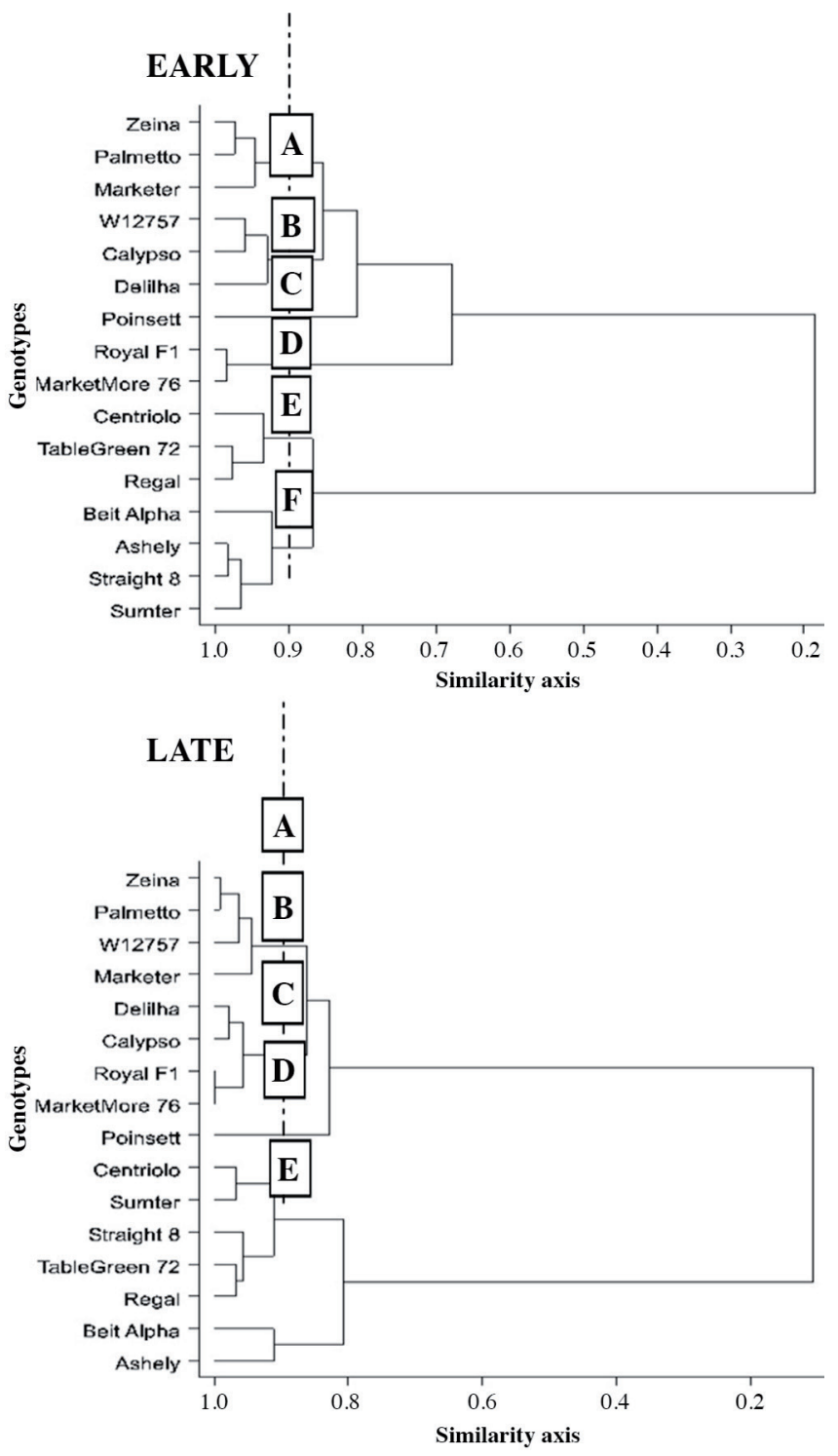
initiation and days to $50 \%$ male and female flowering; this is also an advantage because it encouraged earliness in fruit maturity of the genotypes in the cluster.

For the late planting season, the dendrogram classified the genotypes into four clusters. 'Poinsett' was highlighted as a lone genotype (outlier) just as in the early planting season. Cluster A consisted of 'Zeina', 'Palmetto', 'W12757', and 'Marketer'; cluster B consisted of 'Delilha', 'Calypso', 'Royal F', and 'Marketmore 76' while cluster D included 'Centriolo', 'Sumter', 'Straight 8', 'Tablegreen 72', and 'Regal'. Cluster E was made up of 'Beit Alpha' and 'Ashely'. Cluster E showed the highest mean performance in all the studied traits. The clustering pattern of different genotypes did not follow their geographical distribution and was fairly random. This suggests that genotypes of the same origin that are included in different clusters is an indication of the broad genetic base of the genotypes belonging to the origin. Prasad et al. (2001) reported similar results when they studied 60 inbred lines of cucumber and Osawaru et al. (2013) in their genetic variability study among 53 accessions of West African okra (Abelmoschus caillei [A. Chev.] Stevels). Based on the result of the cluster analysis and a comparison of the means, it was shown that cluster $\mathrm{F}$ from the early season planting and cluster $\mathrm{E}$ from the late planting season expressed the best agronomic characteristics and yield potentials. This implies that selecting for those agronomic traits will provide preference of the genotypes in these clusters over others (Staub et al., 2005).

\section{Principal component analysis (PCA)}

Principal component analysis is an important multivariate technique used to examine associations between characters and measure genotype genetic diversity (Abdi and Williams, 2010). The result of PCA for 16 traits of cucumber genotypes evaluated in 2014 for the early and late planting seasons is presented in Table 5. The first two components accounted for $99.49 \%$ and $99.46 \%$ of the cumulative variation in the population in the early and late planting seasons, respectively. In the early planting season, the first component (PC1) described $93.48 \%$ of the total variation and was positively and highly associated with leaf area and vine length and could therefore be called a vegetative component. The second component axis (PC2) explained $6.01 \%$ of the total variability and was positively associated with vine length whereas leaf area was highly negative. The results for the late plantings followed a similar trend. The PC1 accounted for $92.73 \%$ of the total variation and was also positively and highly associated with leaf area and vine length. The PC2 explained $6.73 \%$ of the total variation and was positively related to vine length whereas leaf area was high but negative. The genetic diversity studies about cucumber quantitative traits based on the multivariate analysis using PCA involved vine length as the most discriminating trait explaining greater variability in cucumber in both the early and late planting seasons and followed by leaf area. The same traits maintained this status in $\mathrm{PC} 2$ as the main tools for
Table 5. Eigen vectors and total percentage variation for the principal component axes of cucumber genotypes evaluated in 2014 early and late planting seasons.

\begin{tabular}{lccccc}
\hline & \multicolumn{2}{c}{ Early planting season } & & \multicolumn{2}{c}{ Late planting II } \\
\cline { 2 - 3 } \cline { 5 - 6 } Attributes & PC1 & PC2 & & PC1 & PC2 \\
\hline D50\%FF & -0.02599 & 0.05005 & & -0.02553 & 0.04153 \\
DFFI & -0.02983 & 0.05632 & & -0.03184 & 0.05893 \\
DMFI & -0.02838 & 0.06045 & & -0.0297 & 0.0508 \\
D50\%MF & -0.02923 & 0.06229 & & -0.02953 & 0.04876 \\
FG & 0.02864 & -0.00714 & & 0.02272 & -0.06368 \\
FL & 0.03386 & -0.00164 & & 0.02725 & -0.07566 \\
FWPP & 0.0047 & 0.00268 & & 0.00508 & -0.01154 \\
LA8WAP & 0.40701 & -0.89894 & & 0.43002 & -0.88067 \\
AFW & -0.00003 & 0.00121 & & 0.00037 & -0.00095 \\
NoB8WAP & 0.01419 & 0.0052 & & 0.01449 & -0.00582 \\
NoFPP & 0.02809 & -0.0371 & & 0.02208 & -0.03333 \\
NoL8WAP & 0.09984 & -0.01737 & & 0.10699 & -0.03508 \\
NoPFPP & 0.01211 & -0.01587 & & 0.00982 & -0.02262 \\
NoSFPP & 0.03068 & -0.05121 & & 0.0315 & -0.06898 \\
TFY ha & 0.01016 & 0.0034 & & 0.01054 & -0.02369 \\
VL8WAP & 0.90387 & 0.41718 & & 0.89277 & 0.44285 \\
Percentage Variation & 93.48 & 6.01 & 92.73 & 6.73 \\
Cumulative Variation & 93.48 & 99.49 & 92.73 & 99.46
\end{tabular}

VL8WAP: vine length $8 \mathrm{wk}$ after planting $(\mathrm{cm})$; LA8WAP: leaf area $8 \mathrm{wk}$ after planting $\left(\mathrm{cm}^{2}\right)$; NoB8WAP: number of branches 8 wk after planting; NoL8WAP: number of leaves 8 wk after planting; DMFI: days to male flower initiation; DFFI: days to female flower initiation; D50\%MF: days to $50 \%$ male flowering; D50\%FF: days to $50 \%$ female flowering; NoPFPP: number of pistillate flowers per plant; NoSFPP: number of staminate flowers per plant; FG: fruit girth (cm); FL: fruit length (cm); FWPP: fruit weight per plant $(\mathrm{kg})$; AFW: mean fruit weight $(\mathrm{kg})$; NoFPP: number of fruit per plant; TFY ha-1: total fruit yield per hectare $\left(\mathrm{t} \mathrm{ha}^{-1}\right)$.

cucumber genotype differentiation. The mean contributions of leaf area and vine length were high in the principal axes. This observation suggests that these traits are major traits explaining most of the variations in cucumber and further contributing to fruit yield in the 16 cucumber genotypes. This partly agrees with results by Nwangburuka (2010) in okra. Therefore, selecting for fruit yield must consider these traits. This corroborates the report by Aremu et al. (2007) in their work with cowpea.

\section{CONCLUSIONS}

The principal component analysis in both seasons showed that selection for vine length and leaf area will increase cucumber fruit yield. These traits should therefore be given special attention in selections aimed at cucumber improvement. Genotype clustering into different groups suggests relatively high genetic variability among genotypes. Results indicated that there is considerable genetic variation in the studied genotypes to warrant selection for both seasons.

\section{REFERENCES}

Abdi, H., and L.J. Williams. 2010. Principal component analysis. Wiley Interdisciplinary Reviews Computational Statistics 2:433-459.

Afangideh, U., and E.A. Uyoh. 2007. Genetic variability and correlation studies in some varieties of cucumber (Cucumis sativus L.) Jordan Journal of Agricultural Sciences 3(4)376-384. 
Afangideh, U., E.A. Uyoh, M. Ittah, and A.E. Uko. 2005. Morphological characterization of some cultivars of cucumber (Cucumis sativus L.) Journal of Sustainable Tropical Agricultural Research 14:13-18.

Ahmed, N.C.B., and I.M.W. Khaliq. 2007. The inheritance of yield and yield components of five wheat hybrid populations under drought conditions. Indonesian Journal of Agricultural Science 8(2):53-59.

Aremu, C.O., M.A. Adebayo, O.J. Ariyo, and B.B. Adewale. 2007. African Journal of Biotechnology 6(20):2333-2339.

Aruah, B.C., M.I. Uguru, and B.C. Oyiga. 2012. Genetic variability and inter-relationship among some Nigerian pumpkin accessions (Cucurbita spp.) International Journal of Plant Breeding 6(1):34-41.

Burton, G.W. 1952. Qualitative inheritance in grasses. Vol. 1. p. 277-283. Proceedings of the $6^{\text {th }}$ International Grassland Congress, Pennsylvania State College. 17-23 August. Pennsylvania State College, Pennsylvania, USA.

Eid, M.H. 2009. Estimation of heritability and genetic advance of yield traits in wheat (Triticum aestivum L.) under drought conditions. International Journal of Genetics and Molecular Biology 1(7):115-120.

Eifediyi, E.K., and S.U. Remison. 2009. Effect of time of planting on the growth and yield of five varieties of cucumber. Report and Opinion 1(5):81-90.

Eneobong, H.N. 2001. Eating right. 161 p. University of Calabar Press, Calabar, Nigeria.

Fehr, W.I. 1987. Principles of cultivar development. Vol. 1. 548 p. Macmillan, New York, USA.

Gatti, I., F.L. Anido, C. Vanina, P. Asprelli, and E. Country. 2005. Heritability and expected selection response for yield traits in blanched asparagus. Genetics and Molecular Research 4(1):67-73.

Haifa Chemicals. 2012. Nutritional recommendations for cucumber (Cucumis sativus L.) in the open fields, tunnel and greenhouse. p. 4-5. Haifa Chemicals, Haifa, Israel.

Idahosa, D.O., J.E. Alika, and A.U. Omoregie. 2010. Genetic variability, heritability and expressed genetic advance as indices for yield and yield components selection in cowpea (Vigna unguiculata (L.) Walp.) Academia Arena 2(5):22-26.

Kehinde, I.A. 2008. Identification and control of field and storage fungal pathogens of egusi melon. (Citrullus lanatus [Thumb]) Mansf in South Western Nigeria. 211 p. PhD thesis. Federal University of Agriculture, Abeokuta, Nigeria.

Khan, A.S.M.M.R., M.Y. Kabir, and M.M. Alam. 2009. Variability, correlation, path analysis of yield and yield components of pointed gourd. Journal Agricultural Rural Development 7(1-2):93-98.

Milatovic, D., D. Nikolic, and D. Durovic. 2010. Variability, heritability and correlation of some factors affecting productivity in peach. Horticultural Science (Prague) 27(3):79-87.

Nausherwan, N.N., M.S. Ghulam, M. Khali, S. Qamar, and S. Akhtar. 2008. Genetic variability, correlation, path analysis studies in garden pea (Pisum sativum L.) Journal of Agricultural Research 36(1):333-340.

Ndukauba, J., G.E. Nwofia, P.I. Okocha, and E.E. Ene-Obong. 2015. Variability in Egusi-Melon Genotypes (Citrullus lanatus [Thumb] Matsum and Nakai) in derived Savannah environment in South-Eastern Nigeria. International Journal of Plant Research 5(1):19-26. doi:10.5923/j.plant.20150501.04.
Nwangburuka, C.C. 2010. Morphological characterization and genetic studies in okra Abelmoschus esculentus (L.) Moench. PhD Thesis. Federal University of Agriculture, Abeokuta, Nigeria.

Olaniyi, O.O., G.O. Ogidi, E.U. Mbah, and E.J.Nya. 2011. Variance in yield and agronomic performance of egusi-melon (Citrullus lanatus [Thumb]) genotypes. International Journal of Current Research 3(11):49-52.

Osawaru, M.E., M.C. Ogwu, and F.M. Dania-Ogbe. 2013. Morphological assessment of the genetic variability among 53 accessions of West African Okra [Abelmoschus caillei (A. Chev.) Stevels] from South Western Nigeria. Nigerian Journal of Basic and Applied Sciences 21(3):227-238.

Papadopoulos, A.P. 1994. Growing greenhouse seedless cucumbers in soil and soilless media. Agriculture and Agri-Food Canada Publication 1902/E. 132 p. Agriculture and Agri-Food Canada, Ottawa, Ontario, Canada.

Prasad, V.S.R.K., B.P. Jain, S.P.P. Verma, and D. Ganguly. 2001. Diversity pattern and choice of parents for hybridization in slicing cucumber (Cucumis sativus L.) Journal of Research of Birsa Agricultural University 13(1):33-39.

Rakhi, R., and L. Rajamony. 2005. Variability, heritability and genetic advance in landraces of culinary melon (Cucumis melo L.) Journal of Tropical Agriculture 43(1-2):79-82.

Sharma, J.R. 1988. Statistical and biometrical techniques in plant breeding. 432 p. New Age International Limited Publishers, New Delhi, India

Staub, J.E., S.M. Chung, and G. Fazio. 2005. Conformity and genetic relatedness estimation in crop species having a narrow genetic base: The case of cucumber (Cucumis sativus L.) Plant Breeding 124:44-53.

Subramanian, A., and N. Subbaraman. 2010. Hierarchical cluster analysis of genetic diversity in maize germplasm. Electronic Journal of Plant Breeding 1(4):431-436.

Tazeen, M., K. Nadia, and N.N. Farzana. 2009. Heritability, phenotypic correlation and path coefficient studies for some agronomic characters in synthetic elite lines of wheat. Journal of Food, Agriculture and Environment 7(3-4):278-282.

Uguru, M.I., K.P. Baiyeri, and S.C. Aba. 2011. Indicators of climate change in the derived savannah niche on Nsukka, South-Eastern Nigeria. Agro-Science 10(1):17-26.

Ullah, M.Z., M.J. Hassan, A.Z.M.K.A. Chowdhury, A.I. Saki, and A.H.M.A. Rahman. 2012. Genetic variability and correlation in exotic cucumber (Cucumis sativus L.) varieties. Bangladesh Journal of Plant Breeding and Genetics 25(1):17-23.

Wehner, T.C. 2007. Cucumbers, watermelon, squash and other cucurbits. p. 474-479. In Encyclopedia of Food and Culture.

Wehner, T.C., and N. Guner. 2004. Growth stage, flowering pattern, yield and harvest date prediction of four types of cucumber tested at 10 planting dates. Acta Horticulturae 637:223-229.

Yadav, Y.C., B.B. Sanjay Kumar, and S.K. Dixit. 2009. Genetic variability, heritability and genetic advance for some traits in Cucumber. Indian Journal of Agricultural Research 8:51-57. 